\title{
Discretionary Fiscal Policy and the European Monetary Union
}

\author{
Jason Jones \\ Department of Economics, Furman University, Greenville, USA \\ Email: jason.jones@furman.edu \\ Received August 10, 2012; revised September 17, 2012; accepted September 26, 2012
}

\begin{abstract}
A model of circumstances that can lead to changes in the way a fiscal authority conducts policy after joining a monetary union is presented and empirically tested for the euro area. According to the model consolidation fatigue, shock asymmetry, or differences in the relative weight placed on output/price stabilization between the new and old monetary authority can lead to greater reliance on fiscal policy. Empirical evidence suggests that there has been a change in the conduct of fiscal policy in the euro area which is most likely due to consolidation fatigue and a stronger emphasis on price stabilization by the European Central Bank.
\end{abstract}

Keywords: Fiscal Policy; Policy Interaction; EMU

\section{Introduction}

The sovereign debt crisis among members of the European Monetary Union (EMU) underscores the need to study fiscal policy in the currency union. In the years immediately preceding the formation of the monetary union the budgetary position of most members improved. Soon after the formation of the monetary union, however, budgetary positions began to deteriorate. The deterioration of fiscal positions in relatively good times made the deficit effects of the global recession in the late 2000 s severe, leading to debt crises and bailouts of some of the member states.

The change in fiscal balances soon after the creation of the EMU suggests that part of the explanation could be tied to the monetary union itself. Understanding how the monetary union has modified the role and preferences of its policymakers can help the union address its deficit challenges. This understanding can also inform states looking to join the EMU, as well as other monetary unions under consideration around the world, of the possible fiscal challenges they may face.

This paper models and tests possible changes to discretionary fiscal policy as a result of becoming a member of the EMU. By expanding Uhlig's [1] model of policy interaction and applying it both before and after the formation of the monetary union, the fiscal challenges of surrendering independent monetary policy are illustrated. Specifically, increased reliance on fiscal management is needed if shocks are dissimilar across members of the monetary union or the policy weights of the new mone- tary authority are different than the former local monetary authority. The model also allows for an exogenous change in the preferences of fiscal authorities to account for consolidation fatigue identified by Hughes-Hallett and Lewis [2].

To test this model and understand how discretionary fiscal policy has changed in the euro area, a fiscal reaction function is estimated allowing for a break at the formation of the monetary union in 1999. Unlike most fiscal reaction function literature, the response to supply and demand shocks rather than the output gap is estimated. The results suggest that there has been a change in the way fiscal authorities respond to supply shocks since becoming members of the EMU. The response becomes counter-cyclical after the formation of the union and is most likely due to a stronger weight by the European Central Bank (ECB) on price stabilization relative to output stabilization compared to the former local monetary authority. Counter-cyclical fiscal responses after the formation of the union could help explain the worsening of budgetary balances. In addition, the fiscal response to debt levels is weaker after the formation of the EMU. This result suggests a role for consolidation fatigue in explaining worsening deficit positions.

The remainder of the paper is structured as follows. In the next section a model of monetary and fiscal policy is constructed that explores the possible reasons for changes in the conduct of discretionary fiscal policy as a result of joining a monetary union. The following two sections introduce the empirical techniques and data used to test how fiscal reactions have changed since the forma- 
tion of the EMU. The final two sections present the results and conclude.

\section{Theoretical Model}

Modeling policy actions in a monetary union can be done in a number of ways. One strand of research models monetary and fiscal interaction in a monetary union using sophisticated micro-founded new-Keynesian general equilibrium models (Benigno [3]; Beetsma and Jensen [4]; Gali and Monacelli [5]; and Michalak, Engwerda, and Plasmans [6]). These models explore welfare effects of optimal and rule based policy with or without policy coordination. These models, however, do not highlight the changes in policy that come as a result of joining the union. In addition, the complexity of these models requires solution methods that mask the salient conditions which could change fiscal management as a result of joining a monetary union.

An alternate and tractable approach to study monetary and fiscal policy in a monetary union focuses on the strategic interaction between the policymakers without the mico-foundations of a macroeconomic model. Dixit and Lambertini [7] model the interaction between a central monetary authority and different independent fiscal authorities to look at what happens if they have different output and inflation targets. Using a similar model, Dixit and Lambertini [8] find that if the monetary and fiscal authorities can agree on the ideal levels of output and inflation, they can disagree about weights and still achieve a first best solution. Beetsma, Debrun, and Klaassen [9] present of model of strategic interaction to explore fiscal coordination. They find that the benefits of coordination depend on the type and symmetry of shocks that affect the union.

A few authors have integrated strategic interactions in the spirit of Dixit and Lambertini $[7,8]$ with static micro-founded model in the spirit of the more complex models of Beetsma and Jensen [4] to provide meaningful, tractable models of policy in a monetary union. Uhlig [1] is one of the first to use this approach to illustrate the dangers of coordination failure in the EMU. Van Aarle, Garretsen, and Huart [10] use a similar model to simulate how different weights in fiscal policy functions can cause nominal divergence. Using similar techniques, Bofinger and Mayer [11] illustrate how shock asymmetry across the union complicates stabilization policy within a union.

In order to illustrate these changes in a relatively simple, comprehensive, and informative manner a static micro-based strategic interaction model similar to $[1,11]$ is used. Unlike [1,11], this model explicitly represents the interaction between policy makers before and after the formation of the union to highlight the possible changes in the conduct of fiscal policy. The model captures the coordination challenges that arise if the shock is an inflation shock relative to an output or demand shock [6]. It highlights the importance of different weights on stabilization priorities [10], as well as the role of asymmetry [11]. The model also presents a role for consolidation fatigue [2].

A typical model with Calvo sticky prices, no capital, and a role for government is used. Following the micro-foundations of such models, the household's optimization conditions, the firm's optimization decision, and the market clearing conditions are represented. In order to provide a tractable solution and clear illustration of the changes in how fiscal and monetary authorities interact before and after the formation of the monetary union, a nondynamic version of the model is used. Using these conditions the log-linearized demand and Phillips curves for each country (i) can be represented by

$$
\begin{aligned}
& y_{i}=-a_{i}\left(i_{i}-\pi_{i}^{e}\right)+b_{i}\left(g_{i}\right)+v_{i} \\
& \pi_{i}=\pi_{i}^{e}+\kappa_{i} y_{i}+u_{i}
\end{aligned}
$$

In these equations, $y$ is the output gap, $i$ is the nominal interest rate, $\pi$ is inflation, $\pi^{e}$ is expected inflation, $v$ is a demand shock (excluding fiscal shocks), and $\mu$ is a supply shock (where a positive shock is inflationary; consistent with a negative supply shock or a cost-push shock). $g$ represents discretionary fiscal policy. An upward movement in $g$ (expansionary policy) causes an increase in output and a worsening of budgetary positions due to either spending increases or tax cuts.

The monetary authority cares about limiting inflation and output gap fluctuations. The monetary authority chooses the nominal interest rate to maximize

$$
-\frac{1}{2}\left(\theta_{i}^{j} y_{i}^{2}+\pi_{i}^{2}\right)
$$

where $\theta^{j}$ is the relative weight the monetary authority places on output gap verses inflation stabilization. ${ }^{1}$ The domestic monetary authority responds to the country specific levels of the output gap and inflation, while the union's monetary authority responds to aggregate levels of the output gap and inflation.

In addition to smoothing output gap and inflation fluctuations, the fiscal authority of each country also wants to limit budgetary fluctuations. Thus the fiscal authority of each country maximizes

$$
-\frac{1}{2}\left(\theta_{i}^{f} y_{i}^{2}+\pi_{i}^{2}+\alpha_{i}\left(g_{i}-\varepsilon_{i}\right)^{2}\right),
$$

where $\theta^{f}$ is the relative weight the fiscal authority places on output gap verses inflation stabilization and can be different than the weight of the monetary authority. $\alpha$ is

${ }^{1}$ Before joining the monetary union, $j=m$ represents the domestic monetary authority. After the formation of the monetary union, $j=M$ represents the new central monetary authority. 
the weight placed on budget stabilization, while $\varepsilon$ is an exogenous fiscal shock which moves the budget away from the steady state level. A positive shock would allow for a higher value of $g$ (larger deficits or smaller surpluses) in the optimal solution. This would entail changes to the budget beyond optimal stabilization, including politically motivated deficit spending that might result from consolidation fatigue.

The timing of policy is important for how the monetary and fiscal authority decide to conduct policy. First, agents form inflation expectations, which before any shocks are realized is zero. After those expectations are formed, shocks hit the economy. Once the shock is realized, the monetary authority responds first. The fiscal authority then responds taking into account the monetary authority's actions. The model is solved using backward induction as the monetary authority takes into account the fiscal authority's optimal response when it makes its policy decision. Beetsma and Bovenberg [12] argue that the long adjustment lag by fiscal authorities relative to the monetary authority justifies this ordering.

Before joining the monetary union, each country has control over its own monetary and fiscal policy. Therefore, each country (i) solves its own individual country specific problem. Solving using backward induction the fiscal authority maximizes its objective function (Equation (4)) subject to the demand curve (Equation (1)) and the Phillips curve (Equation (2)), taking the nominal interest rate as given. The optimal response becomes

$$
\begin{aligned}
& g_{i}= \\
& \frac{1}{\sigma_{i}}\left[a_{i} b_{i}\left(\theta_{i}^{f}+\kappa_{i}^{2}\right) i_{i}-b_{i}\left(\theta_{i}^{f}+\kappa_{i}^{2}\right) v_{i}-\kappa_{i} b_{i} u_{i}+\alpha_{i} \varepsilon_{i}\right],
\end{aligned}
$$

where $\sigma_{i}=\left(b_{i}^{2}\left(\theta_{i}^{f}+\kappa_{i}^{2}\right)+\alpha_{i}\right)$.

The domestic monetary authority takes into account the optimal reaction of the fiscal authority and maximizes its objective function (Equation (3)) with respect to the demand curve (Equation (1)) and the Phillips curve (Equation (2)), as well as the optimal fiscal reaction (Equation (5)). The optimal response of the monetary authority thus becomes

$$
i_{i}=\frac{1}{a_{i}} v_{i}+\frac{\left(\kappa_{i} b_{i}^{2}\left(\theta_{i}^{f}-\theta_{i}^{m}\right)+\kappa_{i} \alpha_{i}\right)}{a_{i} \alpha_{i}\left(\kappa_{i}^{2}+\theta_{i}^{m}\right)} u_{i}+\frac{b_{i}}{a_{i}} \varepsilon_{i} .
$$

Using the optimal monetary reaction, the optimal fiscal reaction function can be calculated by substituting Equation (6) into Equation (5):

$$
\begin{aligned}
& g_{i}= \\
& \frac{\kappa_{i} b_{i}^{3}\left(\left(\theta_{i}^{f}\right)^{2}-\theta_{i}^{f} \theta_{i}^{m}\right)+\kappa_{i}^{3} b_{i}^{3}\left(\theta_{i}^{f}-\theta_{i}^{m}\right)+\kappa_{i} b_{i} \alpha_{i}\left(\theta_{i}^{f}-\theta_{i}^{m}\right)}{\sigma_{i} \alpha_{i}\left(\kappa_{i}^{2}+\theta_{i}^{m}\right)} \\
& u_{i}+\varepsilon_{i}
\end{aligned}
$$

In response to a positive demand shock $(v)$ or expansionary fiscal shock $(\varepsilon)$ the monetary authority raises the interest rate to lower inflation and bring output back to its natural level. The fiscal authority, on the other hand, does not need to respond to a demand shock. Theoretically, both discretionary monetary and fiscal policy tools influence the demand curve. The monetary authority is assumed to respond to shocks first, and thus in the face of a demand shock the monetary authority uses its policy to return the demand curve to its desired position. The fiscal authority knows this will be the monetary authority's response and that this monetary action will be taken before they can respond, so they do not respond themselves.

In the face of a supply shock $(u)$ however, the policy maker must choose between output gap stabilization and inflation stabilization. As a result, supply shocks are more complicated and the fiscal response depends on the relative weight that the monetary and fiscal authority place on output gap stabilization. If stabilization goals are the same $\left(\theta^{f}=\theta^{m}\right)$ the monetary authority raises interest rates in response to a supply shock and there is no fiscal response. The fiscal authority knows this is the monetary authority's optimal response, and with the same stabilization goals there is no need to respond. If their stabilization goals are different $\left(\theta^{f} \neq \theta^{m}\right)$, the monetary authority adjusts its policy in anticipation of the fiscal response, and the fiscal authority acts to overcome both the supply shock and the monetary response.

Once countries become members of the monetary union, their fiscal choices change as the monetary system changes. The union's central bank must react to economy-wide fluctuations. This introduces a mechanism for each member's shocks to have an indirect effect on the economies of the other members. In order to model this, the output gap and inflation to which the union's central bank responds is a weighted aggregate of each individual member's output gap and inflation:

$$
\begin{aligned}
& y^{*}=\Gamma^{\prime} y \\
& \pi^{*}=\Gamma^{\prime} \pi .
\end{aligned}
$$

In these equations, $\Gamma$ is an $(n \times 1)$ vector of weights corresponding to the relative economic size of the union's members. The individual weights add up to one. $y$ and $\pi$ are $(n \times 1)$ vectors of the output gap and inflation of each of the member states.

In solving the problem using backward induction, the domestic fiscal authority, taking the interest rate as given, makes the same decision as before. The only difference is that the interest rate is not dictated by the domestic monetary authority, but by the union's monetary authority. The fiscal optimization result thus becomes 
$g_{i}=\frac{1}{\sigma}\left[a b\left(\theta^{f}+\kappa^{2}\right) i^{*}-b\left(\theta^{f}+\kappa^{2}\right) v_{i}-\kappa b u_{i}+\alpha \varepsilon_{i}\right]$.

In this case, $i^{*}$ is the nominal interest rate dictated by the union's monetary authority. The subscript (i) on the parameters has been dropped because it has been assumed for clarity and illustrative purposes that each country has the same parameters across the union.

The union's monetary authority now takes into account the aggregate output gap and inflation of the member states, as well as the aggregate fiscal reaction, and maximizes

$$
-\frac{1}{2}\left(\theta^{M}\left(y^{*}\right)^{2}+(\pi)^{2}\right) .
$$

The optimal monetary policy for the union's monetary authority thus becomes

$$
i^{*}=\frac{1}{a} \Gamma^{\prime} v+\frac{\left(\kappa b^{2}\left(\theta_{i}^{f}-\theta_{i}^{M}\right)+\kappa \alpha\right)}{a \alpha\left(\kappa^{2}+\theta^{m}\right)} \Gamma^{\prime} u+\frac{b}{a} \Gamma^{\prime} \varepsilon .
$$

In this case, $v, \mu$, and $\varepsilon$ are $(\mathrm{n} \times 1)$ vectors of country specific shocks. This reaction is similar to the domestic monetary authority's actions except the new monetary authority reacts to weighted averages of the country specific shocks. In order to solve for the domestic optimal fiscal policy once the union's monetary authority has acted, it is convenient to rewrite Equation (12) as

$$
\begin{aligned}
i^{*}= & \frac{1}{a} \bar{\Gamma}^{\prime} v+\frac{\left(\kappa b^{2}\left(\theta_{i}^{f}-\theta_{i}^{M}\right)+\kappa \alpha\right)}{a \alpha\left(\kappa^{2}+\theta^{m}\right)} \bar{\Gamma}^{\prime} u+\frac{b}{a} \bar{\Gamma}^{\prime} \varepsilon \\
& +\frac{1}{a} \gamma_{i} v_{i}+\frac{\left(\kappa b^{2}\left(\theta_{i}^{f}-\theta_{i}^{M}\right)+\kappa \alpha\right)}{a \alpha\left(\kappa^{2}+\theta^{m}\right)} \gamma_{i} u_{i}+\frac{b}{a} \gamma_{i} \varepsilon_{i}
\end{aligned} .
$$

Here, $\bar{\Gamma}$ is the $((n-1) \times 1)$ vector of weights $\left(\gamma_{i}\right)$ excluding the weight of country (i). Similarly $v, \mu, \varepsilon$ are the $[(n-1) \times 1]$ vectors of shocks excluding country (i). Plugging Equation (13) into Equation (10) gives the following optimal fiscal response:

$$
\begin{aligned}
g_{i}= & \frac{b\left(\theta^{f}+\kappa^{2}\right)}{\sigma} \bar{\Gamma}^{\prime} v+\left(1-\gamma_{i}\right)\left[-\frac{b\left(\theta^{f}+\kappa^{2}\right)}{\sigma}\right] v_{i} \\
& +\frac{b^{2}\left(\theta^{f}+\kappa^{2}\right)}{\sigma} \bar{\Gamma}^{\prime} \varepsilon+\frac{\gamma_{i} b^{2}\left(\theta^{f}+\kappa^{2}\right)+\alpha}{\sigma} \varepsilon_{i} \\
& +\frac{\kappa b^{3}\left(\theta^{f}-\theta^{M}\right)\left(\theta^{f}+\kappa^{2}\right)+\kappa b \alpha\left(\theta^{f}+\kappa^{2}\right)}{\alpha \sigma\left(\theta^{M}+\kappa^{2}\right)} \bar{\Gamma}^{\prime} u \\
& +\frac{\left(1-\gamma_{i}\right)\left(-\kappa^{3} b \alpha\right)+\gamma_{i} \lambda+\kappa b \alpha\left(\gamma_{i} \theta^{f}-\theta^{M}\right)}{\alpha \sigma\left(\theta^{M}+\kappa^{2}\right)} u_{i}
\end{aligned}
$$

where $\lambda=\kappa b^{3}\left(\left(\theta^{f}\right)^{2}-\theta^{f} \theta^{M}\right)+\kappa^{3} b^{3}\left(\theta^{f}-\theta^{M}\right)$. If shocks and weights are identical across the monetary union, this expression is the same as the one country case. $^{2}$

A comparison of Equation (7), the fiscal authority's optimal reaction before the formation of the union, and Equation (14), the optimal reaction after the formation of the union, illustrates how the role of the domestic fiscal authority could change after the formation of the monetary union. The fiscal authority now must take into account how large its country is in relation to other members as well as how similar country specific shocks are to those in the rest of the union. They also must take into account how the new monetary authority's relative weight on output stabilization may be different than that of the previous domestic monetary authority.

Sufficient similarity in shocks and thus synchronized business cycles was cited by Mundell [13] as a necessary criterion for a group of countries to be an optimal currency area (OCA). The problem of not meeting this OCA criterion for the fiscal authority can be seen by compareing Equations (7) and (14). For example, before joining the union the fiscal authority did not need to respond to any demand shocks, yet after the formation of the union the fiscal authority optimally responds to a demand shock when the country specific shock is different than that of the aggregate shock. Assume a member state experiences a country specific negative demand shock $\left(v_{i}\right)$ while the average demand shock for all members in that period $\left(\bar{\Gamma}^{\prime} \bar{v}\right)$ is positive. The local fiscal authority must now increase deficits (or reduce surpluses) in response to its negative country specific demand shock:

$$
\frac{\delta g_{i}}{\delta v_{i}}=-\left(1-\gamma_{i}\right)\left[\frac{b\left(\theta^{f}+\kappa^{2}\right)}{\sigma}\right]<0 .
$$

At the same time, they must increase spending to overcome the monetary authority's response to the union-wide positive demand shock:

$$
\frac{\delta g_{i}}{\delta \bar{\Gamma}^{\prime} \bar{v}}=\frac{b\left(\theta^{f}+\kappa^{2}\right)}{\sigma}>0 .
$$

Before monetary unification, the country specific fiscal authority did not need to react to its own demand shock, nor was it concerned with the symmetry of that shock (in relation to its neighbors). After joining the union, shock asymmetry would lead to an increased role for the local fiscal authority.

Greater reliance on fiscal policy may also be necessary if the monetary union's central bank has a response function different than that of the country's monetary authority. For example, the union's monetary authority's preference for output stabilization could be less than that of

${ }^{2}$ For example $\bar{\Gamma}^{\prime} \bar{\varepsilon}+\gamma_{i} \varepsilon_{i}=\Gamma^{\prime} \varepsilon=\varepsilon_{M}$ if all fiscal shocks are the same. This relationship is true for each shock. 
the country's prior monetary authority $\left(\theta^{M}<\theta^{n}\right)$. This is a distinct possibility for many countries in euro area with weak domestic central banks. The ECB adopted the German model of central banking (with a strong reputetion for fighting inflation) and a one pillar strategy of monetary policy on inflation stabilization (Wyplosz [14]). In order to maintain the same level of output stabilization as before, a fiscal authority may have to act more aggressively because of the weaker response of the central bank. To illustrate, assume that the shocks that hit the economy are the same so the optimal reaction for the fiscal authority is illustrated by Equation (7). If the weight the monetary authority placed on output stabilization changes, the fiscal reaction changes as follows:

$$
\begin{aligned}
& \frac{\delta g_{i}}{\delta \theta^{j}} \\
& =-\eta\left[\theta^{f} b\left(2 \kappa^{2} b^{2}+\theta^{f} b^{2}+\alpha\right)+\kappa^{2} b\left(\kappa^{2} b^{2}+\alpha\right)\right] u \\
& <0
\end{aligned}
$$

where $\eta=\frac{\kappa}{\sigma \alpha\left(\kappa^{2}+\theta^{j}\right)^{2}}$.

In this case, even if there is a common cost push shock across the union, the fiscal authority increases deficits or reduces surpluses if the new monetary authority is placing less weight on output stabilization ( $\theta^{n}$ falls). The case is similar for demand and fiscal shocks if there is shock asymmetry.

It is also possible that the changes in the deficit are not structural at all, but that greater deficits are a result of changes in political will. In an attempt to meet the deficit criterion of the Maastricht Treaty, most countries had to implement sometimes painful structural as well as temporary changes to their budgets. For example, in the run up to the formation of the monetary union Italy went through major pension reform, raising the retirement age and increasing individual contributions in an attempt to cut down the budget deficit. In addition, temporary adjustments were made that did not change the structure of the deficit but did bring it in line with the Maastricht criteria. Italy used the sale of public assets to increase government revenue, delayed contract renegotiations, and even imposed a temporary Eurotax. Such reforms and one-off measures are hard to maintain especially when the promised returns from joining the union have been slow in coming. Member state populations and politicians may tire from the fiscal constraints imposed on them.

After the formation of the union, the deficit restrictions in the Maastricht treaty were extended under the Stability and Growth Pact (SGP). Under the Maastricht criteria, rule violation would keep a country out of the union. Punishment for violating the SGP, on the other hand, comes in the form of fines. These fines are imposed by fellow members who have little incentive to strap their already strapped neighbors with further financial obligations. In such a way, governments have less incentive to meet the somewhat arbitrary deficit rules, especially when there are economic strains at home. Eichengreen and Wyplosz [15] suggest that European governments traditionally have a deficit bias. If politicians become tired of reform, run out of temporary measures, and see the enforcement of the SGP as weak, then worsening deficits would be expected. Such consolidation fatigue has been identified by Hughes-Hallett and Lewis [2] as an important reason for the worsening of deficit positions after the formation of the monetary union in Europe. In terms of the model, if all the fiscal authorities decided (irrespective of output or price fluctuations) to have higher deficits once they enter the union, fiscal balances will change in a one to one fashion.

\section{Testing the Nature of Responses}

In order to test for possible changes in the conduct of fiscal policy illustrated in the model, a fiscal reaction function is estimated. A fairly standard approach to measuring fiscal reaction functions exists in the literature and consists of estimating versions of the following model:

$$
f_{t}=\varphi_{0}+\varphi_{x} E_{t-1} X_{t}+\varphi_{b} b_{t-1}+\varphi_{d} f_{t-1}+u_{t} .
$$

In this model, current fiscal policy $\left(f_{t}\right)$ is a function of the expected value of a macroeconomic indicator $\left(E_{t-1} X_{t}\right)$, last period's debt level $\left(b_{t-1}\right)$, and last period's fiscal stance $\left(d_{t-1}\right)$. Most studies of fiscal reaction functions use both the cyclically adjusted primary budget balance to measure discretionary fiscal policy and the noncyclically adjusted primary budget balance to study automatic stabilizers. The primary balance is used to remove any influence changes in the interest paid on existing debt may have on the budgetary balance. The macroeconomic indicator most often used is the output gap. To estimate the expected value, most authors use an instrumental variable approach. The debt to GDP ratio is used to capture any fiscal authority's motivation to stabilize debt levels. The lag of the fiscal variable is included to account for possible autocorrelation in the budget decision.

The estimation of fiscal reaction functions in the EMU has received a fair amount of attention in the literature. Most of these explore how deficit restrictions impact the way fiscal authorities operate in the euro area. Gali and Perotti [16] find a change in the conduct of discretionary fiscal policy since the budgetary restrictions were introduced in the Maastricht Treaty. Whereas discretionary fiscal policy was procyclical before Maastricht they have become more counter-cyclical since that time (specifi- 
cally they have become less procyclical). This result indicates that the deficit restrictions have not prevented the fiscal authorities from exercising discretionary fiscal policy as was feared.

Wyplosz [14] finds support for [16] conclusions using the same empirical strategy on updated data. Garciá, Arroyo, Minguez, and Uxó [17] estimate the fiscal rule for each country in the euro area using seeming unrelated regression and find that policy was most procyclical pre-Maastricht, and though it was still procyclical postMaastricht it was not nearly as strong and for many countries it became acyclical. Von Hagen [18], on the other hand, using pooled data instead of panel data finds that discretionary policy has remained strongly procyclical since Maastricht. Balassone, Francese, and Zotteri [19] find no change in the way fiscal policy is conducted since the introduction of fiscal restrictions, but they do find cyclical asymmetry; discretionary policy is countercyclical when there is a negative output gap, but does not respond at all to positive output gaps. Using more current data, Candelon, Maysken, and Vermeulen [20] find that contrary to [16], discretionary policy has remained strongly procyclical since Maastricht.

Due to data restrictions and the emphasis on the deficit restrictions, which change little after the actual formation of the union, only [17] test for changes in fiscal reactions after the formation of the union. They find little change in the way fiscal authorities respond to the output gap when compared to the Maastricht period. These results, however, do not reflect the possible changes to policy that can come as a result of joining the union because they do not identify what types of shocks lead to changes in the output gap. As the model introduced in the previous section predicts, the type of shock is important when looking at fiscal reaction functions before and after joining a monetary union.

Candelon et al. [20] attempt to account for the sources of output gap fluctuations. They use the European Commission's Business and Consumer Survey. Question eight of the Industry/Business Climate Indicator, asks companies about the most important factor limiting their production. Answers of demand or financial constraints are categorized as demand shocks, while responses of labor or equipment were categorized as supply shocks. These responses are aggregated to the country level to create a supply and demand variable for each country in each time period. They find that deficits increase when there are supply constraints on firms, but they decrease when there are demand constraints. This strategy of identifying supply and demand shocks has limitations in terms of our model. Labor or equipment limitations on firm production could be the result of either a supply or a demand shock to the economy as a whole.

Strawczynski and Zeira [21] estimate fiscal reaction functions for twenty-two OECD countries using permanent and transitory shocks in the place of the output gap. To identify these shocks they use the Blanchard and Quah [22] technique of long run-restrictions on a VAR. The use of long-run restrictions in VARs has been used by a number of authors to identify supply and demand shocks in Europe (Bayoumi and Eichengreen [23]; Fidrmuc and Korhonen [24]; and Babetski, Boone, and Maurel [25]). In order to identify structural shocks from a reduced form VAR, certain restrictions, derived from economic theory, must be introduced. Long-run restrictions rely on theoretical differences in how variables respond to shocks at different time horizons. The restrictions used to identify supply and demand shocks are based on assumptions derived from simple Keynesian predictions. Theory suggests that while demand shocks influence prices in the long run, they have no long-run effect on output. Supply shocks, on the other hand, do have permanent effects on both output and prices. The restriction of no demand effects on output in the long run allows for identification using the Blanchard and Quah technique.

These identified shocks more closely match the shocks from the theoretical model presented in the previous sections and are used in the place of the output gap. As a result, the following panel response function is estimated to test the theoretical model and potential changes in fiscal policy:

$$
\begin{aligned}
f_{i, t}= & \varphi_{0}+\varphi_{1} s_{i, t}^{\mathrm{BE}}+\varphi_{2} s_{i, t}^{\mathrm{AE}}+\varphi_{3} d_{i, t}^{\mathrm{BE}}+\varphi_{4} d_{i, t}^{\mathrm{AE}} \\
& +\varphi_{5} b_{i, t-1}^{\mathrm{BE}}+\varphi_{6} b_{i, t-1}^{\mathrm{AE}}+\varphi_{7} f_{i, t-1}+\varepsilon_{i, t}
\end{aligned}
$$

Here, $f$ and $b$ are respectively the fiscal stance and debt level. Supply shocks $(s)$ and demand shocks $(d)$ replace the output gap in Equation (18). Supply shocks, demand shocks, and the debt are split to before (BE) and after (AE) the formation of the EMU. In this way a simple Wald test can be used to determine if there is a difference in the way the fiscal authority reacts to these variables after the formation of the union. The expected value of the supply and demand shocks is not needed as, by definition, they should be surprises. The current value of the supply and demand shocks is used because the data are annual. At this frequency the authorities' have enough time to respond to shocks within the period. ${ }^{3}$

A panel fixed effects estimator as well as the Arellano and Bond [26] two-stage GMM estimator are used to estimate the fiscal reaction function. The Arellano and Bond estimator is used to account for possible correlation between the lagged dependent variable and the unobserved panel-level effects, which would make the fixed effects estimator in a dynamic panel model inconsistent.

\footnotetext{
${ }^{3}$ Robustness tests have been run which use the lag of supply and demand shocks with very similar results.
} 
Robust standard errors are estimated to correct for possible heteroskedasticity.

\section{Data}

The data come from AMECO, the European Commission Economic and Financial Affairs annual macro-economic database and are recorded from 1978 to 2010. Eleven of the original twelve members of the EMU are used in the analysis. ${ }^{4}$ The inclusion of fiscal variables necessitates the use of annual data. Quarterly fiscal variables for Europe are not available until recently and do not provide enough observations to measure fiscal reaction functions pre-EMU. For the VAR used to estimate the supply and demand shocks the growth rate of real GDP and the inflation rate according to the GDP deflator are used. Hannan-Quinn information criterion and Schwarz's Bayesian information criterion indicate an appropriate lag length of one or two for most countries. Chari, Kehoe, and McGrattan [27] highlight that estimation using long-run restrictions is improved the longer the lag length so a lag length of two is chosen. One way to test the validity of the long-run restriction is to generate impulse response functions. According to theory a favorable demand shock should cause an initial increase in output and prices. A favorable supply shock, on the other hand, should cause output to increase and prices to fall. This was observed for all of the countries in the sample with the exception of Germany and Italy.

The dependent variable in the fiscal reaction function $\left(f_{i, t}\right)$ is the cyclically adjusted general government primary balance as a percentage of potential GDP for country $(i)$ at time period $(t)$. The cyclically adjusted balance is used to capture discretionary fiscal policy which is the basis for the theoretical model. Using the primary balance excludes the effect that changing rates of interest (which would be outside of the fiscal authorities' discretion) have on budgetary balances. It also excludes a feature of monetary and fiscal interaction not captured in the model. The lag of the debt to GDP ratio of each country is used for $\left(b_{i, t-1}\right)$.

\section{Results}

The model is first estimated without allowing for changes in the fiscal reaction function as a result of becoming a member of the EMU. Table 1 contains these estimated results:

Columns (1) and (2) are estimated over the whole sample using the Arellano-Bond estimator and the fixed effects estimator respectively. The results are fairly consistent across these two specifications. ${ }^{5}$ The lagged cy-

\footnotetext{
${ }^{4}$ Luxembourg is excluded due to data limitations.

${ }^{5}$ The results are not sensitive to the inclusion of Germany and Italy. Results are available on request.
}

Table 1. Estimated fiscal reaction (no EMU effect).

\begin{tabular}{lcc}
\hline & $(1)$ & $(2)$ \\
\hline Supply & 0.2113 & 0.2059 \\
& $(0.1582)$ & $(0.1734)$ \\
Demand & 0.0836 & 0.1976 \\
& $(0.1731)$ & $(0.1633)$ \\
Debt to GDP ratio (lag) & $0.0222^{* * *}$ & $0.0183^{* * *}$ \\
& $(0.0044)$ & $(0.0039)$ \\
Budgetary balance (lag) & $0.9013^{* * *}$ & $0.8916^{* * *}$ \\
& $(0.1622)$ & $(0.1562)$ \\
\hline
\end{tabular}

Note: Values in parenthesis are robust standard errors using Windmeijer [28] for the Arellano and Bond estimator and using the Huber/White/sandwich estimator for the fixed effects model. ${ }^{* * *}$ Significant at $1 \%$ significant level, ${ }^{* *}$ Significant at $5 \%$ significance level, ${ }^{*}$ Significant at $10 \%$ significance level.

clically adjusted primary balance is positive and significant as expected. The fiscal authorities also respond significantly to the debt to GDP ratio when conducting policy. The positive coefficient indicates that if there is a high debt to GDP ratio last period, deficits are reduced or surpluses are increased this period. This is consistent with the literature which introduces the debt ratio into the fiscal reaction function $[16]{ }^{6}$

The coefficients of most interest are those on the supply and demand shocks. A positive coefficient for a supply shock indicates that as output increases and prices decrease as a result of the shock, the fiscal authority reduces deficits or increases surpluses which is countercyclical to output. A negative sign would indicate procyclical policy in response to supply shocks. Similarly a positive sign on the demand shock coefficient means that as output and prices increase in response to a demand shock deficits are reduced or surpluses are increased, which again is counter-cyclical policy. Neither supply shocks nor demand shocks are significant in the sample as a whole.

Our theory, however, indicates that there could possibly be a change in the way discretionary fiscal policy is conducted after the formation of the union in 1999. To test this theory we estimate Equation (19). The results are presented in Table 2. The Wald tests for differences in particular variables before and after the formation of the union are presented in Table 3.

The reaction to the debt to GDP ratio remains positive and significant before and after the formation of the union. There is a significant difference, however, between the magnitudes of the response. Before the formation of the EMU, the response to debt levels is statistically significantly stronger than it is after the formation of the union. This is consistent with the consolidation fatigue identified by [2]. As the enforcement mechanism on

\footnotetext{
${ }^{6}$ Gali and Perotti [16] use deficits as their dependent variable, whereas the budgetary balance is used here. As a result, a positive coefficient here has the same interpretation as their negative coefficient.
} 
Table 2. Estimated fiscal reaction (with EMU effect).

\begin{tabular}{lcc}
\hline & $(1)$ & $(2)$ \\
\hline Supply $^{\mathrm{BE}}$ & -0.2106 & -0.2256 \\
& $(0.2967)$ & $(0.2433)$ \\
Supply $^{\mathrm{AE}}$ & $0.3279^{*}$ & $0.3324^{*}$ \\
& $(0.1743)$ & $(0.1859)$ \\
Demand $^{\mathrm{BE}}$ & 0.1193 & 0.2478 \\
& $(0.1979)$ & $(0.1639)$ \\
Demand $^{\mathrm{AE}}$ & -0.2116 & -0.1918 \\
& $(0.2517)$ & $(0.2678)$ \\
Debt to GDP ratio $^{\mathrm{BE}}$ (lag) & $0.2515^{* * *}$ & $0.0236^{* * *}$ \\
& $(0.0061)$ & $(0.0048)$ \\
Debt to GDP ratio $^{\mathrm{AE}}$ (lag) & $0.01424^{* *}$ & $0.0122^{*}$ \\
& $(0.0071)$ & $(0.0063)$ \\
Budgetary balance (lag) & $0.9102^{* * *}$ & $0.9070^{* * *}$ \\
& $(0.1578)$ & $(0.1544)$ \\
\hline
\end{tabular}

Note: Values in parenthesis are robust standard errors using Windmeijer [28] for the Arellano and Bond estimator and using the Huber/White/sandwich estimator for the fixed effects model. ${ }^{* * *}$ Significant at $1 \%$ significant level, ${ }^{* *}$ Significant at $5 \%$ significance level, ${ }^{*}$ Significant at $10 \%$ significance level.

Table 3. Wald test-difference in estimated coefficients.

\begin{tabular}{lcc}
\hline & $(1)$ & $(2)$ \\
\hline Supply $^{\mathrm{BE}}=$ Supply $^{\mathrm{AE}}$ & $3.02^{*}$ & $3.20^{*}$ \\
& $(0.0824)$ & $(0.1041)$ \\
Demand $^{\mathrm{BE}}=$ Demand $^{\mathrm{AE}}$ & 1.03 & 2.03 \\
& $(0.3108)$ & $(0.1842)$ \\
Debt/GDP & & \\
(lag $)$ & $11.23^{* * *}$ & $8.99^{* * *}$ \\
& $(0.0008)$ & $(0.0134)$ \\
\hline
\end{tabular}

Note: Values in parenthesis are the associate p-value; ${ }^{* * *}$ Significant at $1 \%$ significant level, ${ }^{* *}$ Significant at 5\% significance level, ${ }^{*}$ Significant at $10 \%$ significance level.

deficit and debt restrictions weakened in the move from the Maastricht Treaty to the SGP governments became lax in meeting the criteria. This particular change in fiscal policy can be accounted for by the epsilon in the theoretical model as it reflects a political decision outside of the desire to stabilize output and price fluctuation.

As the theoretical model predicted, the fiscal response to demand shocks is insignificant before the formation of the monetary union. The model does, however, allow there to be more active fiscal responses to demand shocks after the formation of the union if local demand shocks are sufficiently different than those of the rest of the union. These results however indicate that there is still no significant response to demand shocks after the formation of the union and that this response is no different than before the formation of the union. This suggests that demand shocks are sufficiently similar across the union as to not necessitate active fiscal policy.

The results in Tables 2 and $\mathbf{3}$ suggest that there has been a change in the way fiscal authorities respond to supply shocks. There is no significant response to supply shocks before the formation of the union. This is consistent with the theoretical model if the weight monetary and fiscal authority place on output stabilization relative to price stabilization is similar. After the formation of the union, the fiscal authority begins to react to supply shocks in a counter-cyclical manner. This change in fiscal behavior is consistent with the model's prediction if supply shocks are sufficiently different across member states or if the relative weight the ECB places on output and price stabilization are significantly different than the original domestic monetary authority.

There have been a number of studies that look at business cycles synchronization and shock similarity in the euro area. De Haan, Inklaar and Jong-a-Pin [29] summarize the vast literature and conclude that the euro area has gone through periods of both convergence and divergence. Most studies, however, agree that euro area business cycles have become more synchronized since 1991. There are a number of studies that look specifically at supply and demand shock similarities in the euro area. These studies find that supply shocks across Europe are more correlated than demand shocks. Since supply shocks are more correlated than demand shocks and our results suggest that the asymmetry in demand shocks is not large enough to cause changes in fiscal policy, it is unlikely that asymmetry is the cause of the detected change.

In addition, recent evidence suggests that asymmetry should become less of a concern as Europe becomes more integrated. Clark and Wincoop [30] find the greater economic integration in Europe has led to greater synchronization of business cycles. This relationship in general has been identified by a number of other authors as well (most are based off of Frankel and Rose [31]). Their results suggests that shock asymmetry and idiosyncratic business cycles do not explain a greater need to rely on fiscal policy, and as countries become more integrated this concern should become less important.

Therefore, the change is most likely due to changes in the weight the ECB is placing on output relative to price stabilization when compared to the original monetary authority. Fiscal policy after the formation of the union has become clearly counter-cyclical. This indicates that the ECB is placing greater relative weight on price stabilization than the previous local monetary authority. In order to maintain the same level of output stabilization obtained before the formation of the union, they now actively conduct counter-cyclical fiscal policy. The evidence of a change in the stabilization preferences in the central banks is consistent with the adoption of the German model to central banking and the one pillar strategy of monetary policy on inflation stabilization. This discipline and credibility was lacking for many members of the EMU with their own monetary authority. 


\section{Conclusions}

After the formation of the monetary union in 1999, fiscal balances began to deteriorate. The deterioration of the fiscal balances in relatively good times made the deficit problems of the global recession in the late 2000s severe, leading to debt crises and bailouts for some of the member states. The timing of the reversal in budgetary balances suggests that the formation of the monetary union played a role in the observed changes to fiscal policy. Much of the literature suggest consolidation fatigue, as a result of the stringent and enforceable deficit requirement of the Maastricht treaty coupled with the weak enforceability of the deficit restrictions under the SGP after the formation of the union, caused the reversal. This paper does find support for the consolidation fatigue hypothesis, but it also explores how changes to the conduct of fiscal policy could be a byproduct of joining a monetary union in general.

A model of monetary and fiscal policy interaction before and after the formation of a monetary union illustrates how greater reliance on discretionary fiscal policy is required if country specific shocks are asymmetric to those of the rest of the union or if the weight the union's monetary authority places on price stabilization relative to output stabilization is different than that of the premonetary union local monetary authority. The model is empirically tested for the euro area using a fiscal reaction function that allows for a break at the formation of the union.

The empirical results match model predictions and identify which features of the monetary union have influenced fiscal policy. Since the formation of the union, individual member states have conducted counter-cyclical fiscal policy in response to supply shocks. There was no significant response to supply shocks in the run up to the formation of the union. This result, coupled with the fact that there is no detectable response to demand shocks before or after the formation of the union, suggests that the ECB's relative weight on price stabilization is greater than that of the monetary authorities in the individual countries before the formation of the EMU. Member states trying to maintain the same level of output stabilization as they had before the formation of the union must use fiscal policy more than they did when they had their own monetary authority with which they had a more similar weight on output/price stabilization. This increased reliance on fiscal stabilization policy, in addition to consolidation fatigue, contributed to the change in fiscal stances observed after the formation of the EMU.

\section{REFERENCES}

[1] H. Uhlig, "One Money, But Many Fiscal Policies in Eu- rope: What Are the Consequences," CEPR Discussion Papers No. 3296, 2002.

[2] A. H. Hallett and J. Lewis, "European Fiscal Discipline before and after EMU: Crash Diet or Permanent Weight Loss," Macroeconomic Dynamics, Vol. 12, No. 3, 2008, pp. 404-424.

[3] P. Benigno, "Optimal Monetary Policy in a Currency Area," Journal of International Economics, Vol. 63, No. 2, 2004, pp. 293-320. doi:10.1016/S0022-1996(03)00055-2.

[4] R. Beetsma and H. Jensen, "Monetary and Fiscal Policy Interactions in a Micro-founded Model of a Monetary Union," Journal of Macroeconomics, Vol. 26, No. 2, 2005, pp. 357-376. doi:10.1016/i.jmacro.2003.11.017.

[5] J. Gali and T. Monacelli, "Optimal Monetary and Fiscal Policy in a Currency Union," Journal of International Economics, Vol. 76, No. 1, 2008, pp. 116-132.

[6] T. Michalak, J. Engwerda and J. Plasmans, "Strategic Interactions between Fiscal and Monetary Authorities in a Multi-Country New-Keynesian Model of a Monetary Union," CESifo Working Paper, No. 2534, 2009.

[7] A. Dixit and L. Lambertini, "Monetary-Fiscal Policy Interaction and Commitment versus Discretion in a Monetary Union," European Economic Review, Vol. 45, No. 4-6, 2001, pp. 977-987. doi:10.1016/S0014-2921(01)00134-9.

[8] A. Dixit and L. Lambertini, "Symbiosis of Monetary and Fiscal Policies in a Monetary Union," Journal of International Economics, Vol. 60, No. 2, 2003, pp. 235-247. doi:10.1016/S0022-1996(02)00048-X.

[9] R. Beetsma, X. Debrun and F. Klaassen, "Is Fiscal Policy Coordination in EMU Desirable," CESifo Working Papers, No. 599, 2001.

[10] B. Van Aarle, H. Garretsen and F. Huart, "Monetary and Fiscal Policy Rules in the EMU," German Economic Review, Vol. 5, No. 4, 2004, pp. 407-434. doi:10.1111/j.1465-6485.2004.00115.x.

[11] P. Bofinger and E. Mayer, "Monetary and Fiscal Policy Interaction in the Euro Area with Different Assumptions on the Phillips Curve," Open Economy Review, Vol. 18, No. 3, 2007, pp. 291-305. doi:10.1007/s11079-007-9039-3.

[12] R. Beetsma and A. Bovenberg, "Monetary Union without Fiscal Coordination may Discipline Policymakers," Journal of International Economics, Vol. 45, No. 2, 1998, pp. 239-258. doi:10.1016/S0022-1996(98)00031-2

[13] R. Mundell, "A Theory of Optimal Currency Area," American Economic Review, Vol. 51, No. 4, 1961, pp. 657-665.

[14] C. Wyplosz, "European Monetary Union: The Dark Side of Major Success," Economic Policy, Vol. 21, No. 46, 2006, pp. 207-261.

[15] B. Eichengreen and C. Wyplosz, "The Stability Pact: More than a Minor Nuisance," Economic Policy, Vol. 13, No. 26, 1998, pp. 65-113.

[16] J. Gali and R. Perotti, "Fiscal Policy and Monetary Integration in Europe," Economic Policy, Vol. 18, No. 37, 
2003, pp. 533-572.

[17] A. García, M. Arroyo, R. Minguez and J. Uxó, "Estimation of a Fiscal Policy Rule for EMU Countries," Applied Economics, Vol. 41, No. 7, 2009, pp. 869-884.

[18] J. Von Hagen, "Fiscal Rules and Fiscal Performance in the EU and Japan," GESY Discussion Paper, No. 147, 2006.

[19] F. Balassone, M. Francese and S. Zotteri, "Cyclical Asymmetry in Fiscal Variables in the EU," Empirica, Vol. 37, No. 4, 2010, pp. 381-402. doi:10.1007/s10663-009-9114-7

[20] B. Candelon, J. Muysken and R. Vermeulen, "Fiscal Policy and Monetary Integration in Europe: An Update," Oxford Economic Papers, Vol. 62, No. 2, 2010, pp. 323349. doi:10.1093/oep/gpp017

[21] M. Strawczynski and J. Zeira, "Cyclicality of Fiscal Policy: Permanent and Transitory Shocks," CEPR Discussion Paper, No. DP271, 2009.

[22] O. Blanchard and D. Quah, "The Dynamic Effects of Aggregate Demand and Supply Disturbances," American Economic Review, Vol. 79, No. 4, 1989, pp. 655-673.

[23] T. Bayoumi and B. Eichengreen, "Shocking Aspects of European Monetary Unification," NBER Working Papers, No. 3949, 1992.

[24] J. Fidrmuc and I. Korhonen, "Similarity of Supply and Demand Shocks between the Euro Area and the CEECs," Economic Systems, Vol. 27, No. 4, 2003, pp. 313-336. doi:10.1016/j.ecosys.2003.05.002
[25] J. Babetski, L. Boone and M. Maurel, "Exchange Rate Regimes and Supply Shock Asymmetry: The Case of the Accession Countries," Journal of Comparative Economics, Vol.32, No. 2, 2004, pp. 212-229.

[26] M. Arellano and S. R. Bond, "Some Tests of Specification for Panel Data: Monte Carlo Evidence and an Application to Employment Equations," Review of Economic Studies, Vol. 58, No. 194, 1991, pp. 277-297. doi: $10.2307 / 2297968$

[27] V. Chari, P. Kehoe and E. McGrattan, "Are Structural VaRs with Long-Run Restrictions Useful in Developing Business Cycle Theory," Journal of Monetary Economics, Vol. 55, No. 8, 2008, pp. 1337-1352. doi:10.1016/j.jmoneco.2008.09.010

[28] F. Windmeijer, "A Finite Sample Correction of the Variance of Linear Efficient Two-step GMM Estimators," Journal of Econometrics, Vol. 53, 2005, pp. S121-S169.

[29] J. De Haan, R. Inklaar and R. Jong-a-Pin, "Will Business Cycles in the Euro Area Converge? A Critical Survey of Empirical Research," Journal of Economic Studies, Vol. 22, No. 2, 2008, pp. 234-273.

[30] T. Clark and E. van Wincoop, "Borders and Business Cycles," Journal of International Economics, Vol. 55, No. 1, 2001, pp. 59-85.

[31] J. Frankel and A. Rose, "The Endogeneity of the Optimal Currency Area Criteria,” Economic Journal, Vol. 108, No. 449, 1998, pp. 1009-1025. doi:10.1111/1468-0297.00327 